Journal of Educational Method and Technology Vol. 2 No. 3, Desember 2019

P-ISSN 2622-8459 E-ISSN 2622-8467

http://ejournal.unima.ac.id/index.php/jemtec

\title{
An Analysis Of Learning Materials Needs Of Japanese Language At Nursing School In Tomohon City
}

\author{
R J Kapoh ${ }^{1}$ \\ Universitas Negeri Manado, Indonesia \\ corresponding author: ${ }^{1}$ rutykapoh@unima.ac.id
}

\begin{abstract}
This study aims to produce an overview of the needs of Japanese teaching materials at the Tomohon "Bethesda" Nursing Academy. The approach and method used is a mixed approach or a mixed method that is a research approach that combines qualitative and quantitative forms. Creswell, (2014: 5) Data obtained by observation, survey and interview techniques. By using a mixed method approach, the data collected in the form of text are described qualitatively. Likewise with data through a questionnaire, tabulated in percentage and subsequently described qualitatively. The results of the needs analysis show that both learners and instructors, all of them need teaching materials that the contents of the material in a variety of skills should be in accordance with the special field of expertise that is the field of nursing that is well-graded, and well designed too. Furthermore, in the learning process it should also be equipped with cassettes, videos, and sufficient practice questions and good evaluation. This study recommends that teaching materials be developed that reflect comprehensive needs in the area of health expertise, especially nursing.
\end{abstract}

Keywords: Needs Analysis, Japanese Language Teaching Materials, School of Nursing.

\section{Introduction}

The Vocational School of Nursing in the City of Tomohon especially the Nursing Academy of "Bethesda" Tomohon is a nursing education institution that is collaborating with the "Angin Selatan" Foundation in preparing skilled Japanese workers. Students of the Nursing Academy "Bethesda" Tomohon (hereinafter written by AKPER Bethesda students) are students who are prepared as candidates for internship, in nursing homes in Japan. Furthermore, nurses graduated from AKPER Bethesda are prepared for internships in various nursing homes and hospitals and even in other companies in Japan. Before the internship, the prospective students are expected to be skilled in Japanese in accordance with their work needs, and of course are expected to be able to communicate well with fellow employees, and be able to live well with the community and the environment in which it is located. To meet these demands, it is necessary to set competency standards to be achieved by students while attending education at Akper Bethesda Tomohon. 
Japanese language education for prospective practices or internships is education that equips its participants with a variety of Japanese language skills related to work both in nursing homes or hospitals. In connection with that so that learning objectives can be fulfilled, it is necessary to prepare good teaching materials and in accordance with the needs in the field of work. For this reason it is necessary to analyze the need for appropriate teaching materials regarding the content and subject matter.

Teaching materials are all forms of materials used to help teachers / instructors in carrying out teaching and learning activities in class. According to Tomlinson, the intended material can be written or unwritten or linguistic, visual, auditoy or kinaesthetic, which can be printed out, through live performance or display, or in the form of tapes, CD-ROMs, DVDs, or the internet (2007:2).

Good and quality textbooks, according to Rubdy in Tomlinson, are books that have fulfilled three categories of validity in relation to students, teachers, and material, namely; Psychological validity, Pedagogical validity, and Process and content validity (2007: 45)

Good teaching materials are certainly expected to enable students to be active and try, as well as to be more dominant and active in building their own knowledge in the learning environment, and teaching materials are carried out through a thorough assessment process and through analysis of learner needs. This is consistent with the opinion of Wiggins and Mothighe (2006: 14). which states that the needs analysis is the first step to understanding the needs of students for a learning program. Understanding the needs of students is very important in order to determine the right material.

The main purpose of the analysis is to get an understanding of the information that has been obtained and apply it to several contexts and relevant / appropriate perspectives, and factors of existence that might be in a situation where Richard's gap occurs (2005: 66). Grabowski states that in terms of learning the purpose of this analysis is to obtain adequate information in establishing a policy whether there will be learning interventions or not. If there are interventions, information that needs to be known is what material should be taught, in what order, what media are used, and which methods or delivery strategies are suitable for certain participants may be in a situation where Richard's gap (2005: 66).

Based on the background stated above, the research on the Japanese School of Nursing School's teaching material needs in the city of Tomohon was carried out based on various theories put forward below.

a) Needs Analysis

The term needs according to Brindley in Richards is sometimes used to refer to wants, demands, expectations, motivations, deficiencies, limitations and requirements. Richards further argues that the needs in the field of linguistics, often described as the difference between a student's language skills at present with the language skills that must be possessed by a student, or the difference between science and das solen. This shows that needs have objective reality and are just waiting to be identified and analyzed. (2005: 54) Sanjaya (2010: 91) argues that need assessment is the process of gathering information about gaps to be resolved. Correspondingly, Arcaro (2007: 31) says that assessment ensures that we get the right results. 
Journal of Educational Method and Technology Vol. 2 No. 3, Desember 2019

P-ISSN 2622-8459 E-ISSN 2622-8467

http://ejournal.unima.ac.id/index.php/jemtec

\section{b) Situation analysis}

Klinghammer 1997 in Richards suggested that situation analysis aims to identify key factors that are positive or negative that influence the implementation of curriculum plans. This is sometimes known as a SWOT analysis because it involves examining the "internal strengths of language programs and weaknesses in addition to external opportunities and threats in the presence or success of operations of language programs" Richards (2005: 105106).

The function of the situation analysis is to help identify potential obstacles to implementing the curriculum project and the factors that need to be considered when planning project parameters. The next step in curriculum planning involves using information collected during needs analysis and situation analysis as a basis for developing program goals and objectives. The steps taken in the situation analysis are almost the same as those carried out in the needs analysis. namely: a). consultations with representative and related groups such as parents, students, teachers, administrative staff, government, b). study and analysis of documents such as government reports, instructions from the ministry of education, teaching materials, and curriculum documents; c) observing the learning process, d) opinion surveys from related groups, and e) reviewing various literature relating to the subject matter.

Several factors are of concern in a situation analysis, namely: 1). Social Factors, 2). Project Factors, 3). Institutional Factors, 4). Teacher Factors, 5). Learner Factors, and 6). Adoption Factors. Richards (2005: 93-105).

\section{c) Language learning for specific purpose}

The term language for special purposes (Language for Specific Purpose) has long existed and is known through learning English called English for Specific Purpose-ESP. The following is explained more about the understanding of ESP and the types of ESP.

\section{1) Definition of ESP}

According to Barnard and Zemach, English for Specific Purposes (ESP) is a term that refers to English learning for learners who learn languages for a job or for a purpose related to study. There are two main areas of ESP namely; 1) English for Occupational Purposes (EOP) which enables students to use English in their profession or occupation, and 2). English for Academic Purposes (EAP), which equips students with the correct English language skills to be used in classes / lectures in English, or to present, to research and publish their work in academia. Barnard, and Zemach (2007: .306-307). The above definition is in line with Platt's opinion that ESP language training focuses on the design and delivery of courses for: 1) academic students in specific graduates and undergraduate disciplines, and 2), learners working or preparing to work in business, industry, government, or other places of employment Platt (1996: 3).

The definition proposed by both Barnard and Zemach and by Platt above is closely related to the opinion of Huthinson and Waters that defines ESP as a barrier to language learning that emphasizes the needs of learners in accordance with their specialization in relation to their work or study, and from that need arises the aim is to study. Hutchinson and Waters (1987: 8).

According to Richard ESP began to be incorporated into language teaching in 
the 1980s which was when the emergence of a "needs-based philosophy" in many parts of the world. ESP was included in learning in response to the following: 1. The need to prepare for the growth in the number of non-English speaking students studying at American and British universities since the 1950s. 2. The need to prepare materials to be taught to students who are generally already proficient in English but need English to be used in work. For example, doctors, nurses, engineers and scientists who have no English background. 3. The need for teaching materials for people who need English for business purposes, and 4 . The need to teach the language needed by immigrants in relation to their work. Richard (2005: 28).

From the opinions above, it can be stated that ESP learning is carried out based on needs that are in accordance with specific fields or objectives. Thus it can also be concluded that language learners for special purposes, learn languages not to deepen a particular language. Language learners for special purposes try to learn and master the language which will be used as a medium for learning material that is suitable for its purpose. For students for academic purposes (EAP), they will use the language for learning such as medicine, law, social and culture, and so on. As for students for work purposes (EOP), they will try to master a language related to their work later.

Japanese language learning for special purposes means that language learning for special fields and studies is appropriate to the field of science and profession of the Japanese language user. The opinion of the experts above is of course also very related to the preparation of curriculum, syllabus, and teaching materials that must be adjusted to the needs of these learners. Cunningsworth (1995: 132133). Based on the results of the needs analysis, a good curriculum, syllabus and teaching material can be prepared because the results of the analysis form the basis of the preparation of material that will be used as material for language learning for special purposes. In addition, it can also be obtained information that can be analyzed so that it can determine the material to be taught or what topics are suitable so that it can develop a teaching material.

\section{2) Types of $E S P$}

According to Robinson there are several types of ESP with various abbreviations which basically consist of two main parts namely EOP and EAP. EOP (English for occupational purposes), relating to the needs and training for employment, and EAP (English for Academic purposes), relating to academic or study needs. Robinson (1991: 2). Furthermore, the two main parts are then divided into several sections that are more specific according to the field or needs. The division of ESP referred to, is visualized in the "ESP family tree" as stated by experts. "ESP family tree" according to Robinson, is presented through Figure 1 on the following page.

In the picture, ESP is divided into two main parts namely EOP (English for Occupation Purposes) and EAP (English for Academic Purposes). EOP consists of Pre-Experience, Simultaneous / In-service, and Post-Experience. EAP is divided into Study in Specific Discipline, and As a School subject. Furthermore, Study in Specific Discipline is divided into three parts namely; Pre-Study, InStudy, and Post-Study. While the As a School subject is divided into Independent, and Integrated. 


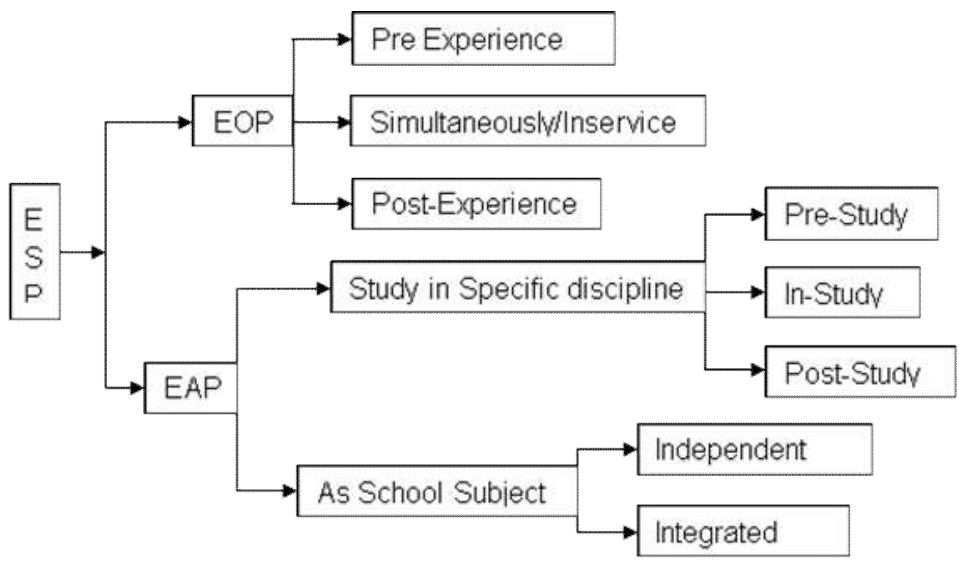

Picture 1. ESP "family tree" according to Robinson

Based on the pictures and explanations presented above, it is possible to suggest that Japanese language learning for vocational schools can be classified as ESP in the EOP (English for Occupation Purposes) branch.

\section{Research Purpose}

The purpose of this study is to understand, describing and describing the need for Japanese School of Nursing teaching materials in Tomohon City.

\section{Research Methods}

The approach used in conducting this research is a mixed method approach. The mixed method approach according to Creswell is a research approach that combines qualitative and quantitative forms by involving philosophical assumptions, application of qualitative and quantitative approaches and mixing between the two approaches in one study. Creswell, (2014: 5) According to Emzir this mixed methods approach uses a research strategy that involves collecting data both simultaneously and sequentially to understand the problem as well as possible. In addition, data collection also involves obtaining information in the form of numerical data obtained through instruments, as well as text information obtained through interviews so that the final database represents both quantitative and qualitative information. Emzir (2014: 28-29) Thus both the data (quantitative and qualitative) can be used together. However, as stated by Glaser and Strauss in Moleong that the two forms of data are needed does not mean 'one test the other' but both are used together and when compared then each can be used for the purposes of developing theory. . Moleong (1988: 19).

This study uses a mixed methods approach because in this study requires the application of two methods namely qualitative and quantitative in order to be able to obtain a better understanding. A qualitative approach is used in research that is subjective or that cannot be controlled, that is, in terms of gathering data on needs analysis obtained through observation and interviews. While the quantitative approach is used to analyze the results obtained from the distribution of needs analysis questionnaires by determining the number and percentage that arise.

Data collection techniques carried out through observation, interviews, and questionnaires. Types of data and data sources are as follows. Data about the need 
Journal of Educational Method and Technology Vol. 2 No. 3, Desember 2019

P-ISSN 2622-8459 E-ISSN 2622-8467

http://ejournal.unima.ac.id/index.php/jemtec

for teaching materials is the main data source of students and teachers, and as a source of supplementary data is a tourism entrepreneur.

\section{Research Result \\ Result of Needs Analysis}

The needs analysis was carried out in the research and development of the Japanese teaching material model of the Nursing School in the city of Tomohon through three activities, namely: 1) Questionnaire distributed to students and instructors, 2) Direct observation when implementing learning in class, and 3). Interview with learners, instructors and users. First of all presented the results of the analysis of student needs. as follows:

\section{a) Students' Needs Analysis}

Analysis of student needs is grouped into three main components, namely: a). components of teaching materials $b$ ). Methods of learning and teaching Japanese. and c). Japanese Language Evaluation. Respondents' answers are presented in the highest order and for answers that are not responded to or below $40 \%$ will not be stated or will not be included as needs.

In the teaching material component consists of 17 questions with several choices of answers to each question. The first, about aspects needed in teaching materials are: interesting, there is a list of words and their meanings, pictured / colored, and there needs to be a tape / tape recorder / video (in contextual learning in the modeling aspect). The second question about the adequacy of the teaching material currently available is sufficient answers only to writing, listening and vocabulary. As for conversation, reading, and grammar it is not enough because it only gets $23.08 \%$. The third question about the suitability of the topic in the existing teaching materials then all say is not suitable for all types of skills because the answers are all below 40\%. Furthermore, almost all respondents said that they need to include topics that are appropriate for all types of skills and other aspects of language. In this section students propose to add examples of conversations that are appropriate to the field of nursing. On questions about the adequacy of the exercises and questions on teaching materials that are being used the students' answers are only on writing (80\%), listening, reading, and vocabulary only $70 \%$ while speaking and grammar are not enough. Furthermore, to improve the ability in the four types of skills (listening (Chookai), speaking (Kaiwa), reading (dokkai), and writing (sakubun), students need a list of words and their meanings (Goi), dialogues in Japanese, .Bunpo ( grammar and explanation), Japanese tapes, training materials (sentences) complete with how to pronounce and intonation, and additional materials.

It is also expected to arrange teaching materials from easy to difficult and which are equipped with a lot of practice questions. Because it is very helpful in understanding the material. (Inquiry) According to most students $(92.67 \%)$ the questions in the textbook used now it's not too difficult. Therefore, it is recommended to arrange more challenging questions (inquiry).

In the component of teaching and learning method as explained above, it consists of 30 questions which are summarized in six tables and then followed by an explanation in accordance with the answers or comments of students. The methodology section is concluded as follows: 
First, for learning methods and strategies for listening and speaking skills students must; often practice listening to Japanese utterances, mastering bunpou (grammar), often hearing Japanese tapes, adding vocabulary, speaking time, getting used to hearing people who speak Japanese and not feeling ashamed when mispronouncing, often listening to Japanese radio broadcasts and often practices in a language laboratory.

For learning strategies to read, students must: frequently read Japanese texts, add vocabulary, master bunpou (grammar), often practice translating Japanese, have a strong will to learn Japanese, get used to reading Japanese books / magazines / newspapers, and often read Japanese stories / comics / novels. While writing learning strategies students must: often practice writing, get used to arrange words into sentences, master bunpou (grammar), often practice making Japanese sentences with words that are already mastered, add to the vocabulary, and often practice composing sentences and paragraph.

Learning strategies and mastering grammar, learners must; diligently working on questions in the book or assignments from the instructor, exercises to arrange words into sentences, memorizing sentence patterns, exercises working on grammar problems such as changing verbs, and diligently asking questions both to the teacher or to friends (constructivism and questioning). While the vocabulary learning strategies are: memorizing words, writing words that have been memorized into sentences, writing definitions of words in Japanese, looking for similarities and differences in meaning, looking for meanings of words in a dictionary, and saying new words and write in sentences. In the case of difficult word pronunciation, the learner proposes to write down the pronunciation (intonation and accent).

In connection with the teacher's teaching method, the learner proposes to be varied with the reasons: 1) so that students are easy to understand and be able to practice it, 2) students are happy and not bored, and 3) students are free to learn with a sense of comfort, relaxation and creativity. Japanese Language Evaluation Component. According to students the exam questions carried out today are still not very influential. Forms and assessment techniques in Japanese should be made in pairs and groups, especially for speaking and listening skills, except in the form of an interview test, it may be in the form of an independent test. Forms of assessment of reading and writing skills should also be varied. Because other skills are also very supportive. For example, for writing skills, besides writing they are also given tasks such as composing words and sentences, developing into paragraphs to the completion of a writing creatively and with clear understanding. For reading skills, the problem is that in addition to answering questions about text, dialogue and questions from other sources also need.

b) Teacher Needs Analysis

Analysis of teacher needs is based on seven components namely; rational, subject and content, gradations, methodology, design and layout, exercises and other components. On the subject and content component, most respondents need authentic material, $100 \%$ expect material that is appropriate to the field of study, varies and according to the level of learners. Teaching material should be integrated between four skills plus grammar and vocabulary (whole language). Then, the purpose of teaching should also be written clearly. It also comes with 
Journal of Educational Method and Technology Vol. 2 No. 3, Desember 2019

P-ISSN 2622-8459 E-ISSN 2622-8467

http://ejournal.unima.ac.id/index.php/jemtec

dialogues, pictures, vocabulary lists, grammar and explanations, lists of verbs and changes, teacher instructions, student instructions, and answer keys, so that textbooks are interesting, and have clear instructions.

Examples of material for speaking skills proposed by the teacher include: conversations with patients or the elderly, listening materials such as: listening to stories / complaints of the elderly and followed by speaking statements. On reading material for example translating parts or equipment in the elderly bedroom, plus reading information. Next on writing material, such as life and activities in nursing homes, or making a report of activities in one day, supplemented by writing information.

In the Vocabulary (Goi) material it is also proposed to include words in the field of nursing, and grammar containing polite forms (talking to guests) and followed by sentence patterns. In the gradation component all respondents suggested that materials made for all types of skills be arranged regularly from simple to more complicated, or from easy to more difficult. In the methodology section, respondents propose to be able to pay attention to students' different learning patterns. For this reason, it is necessary to develop materials with varied and interesting learning methods. In the listening section there is a need for native speakers or native speakers, or cassettes. (modeling). In the methodology section also the respondents stated the need to create a natural interaction to stimulate students' way of thinking more globally.

In the design and layout section, respondents generally need teaching materials that are beautifully and artistically designed, containing colorful images and attractive appearance. For the additional training component, it is very necessary to involve vocabulary training, grammar and writing (learning community and authentic assessment). In addition, additional components such as cassettes, videos, teacher's instructions, and student's instructions are also needed. Furthermore, the results of the interview analysis about the needs carried out through three sources, namely students, teachers and entrepreneurs are essentially the same, all of them need teaching materials that are appropriate to the field of nursing.

The results of the analysis of the documents obtained indicate that the teaching material currently being used at the School of Nursing in Tomohon City is currently too general and has no specificity so it is not in accordance with the vocational field, both the topic and material. Referring to the data obtained on the needs analysis results and the data analysis results of the document above, it can be concluded that it is necessary to develop a teaching material model that is in line with the needs of students and instructors at the Nursing School in the city of Tomohon. Based on the data above, what is needed is teaching material that is able to increase student competence, able to increase student activity, and teaching materials that are appropriate to the characteristics of students, as well as interesting and fun teaching material.

\section{Discussion}

In the process of research and analysis of the Japanese language teaching material needs of the Nursing School in the city of Tomohon that have been done can be stated several things that are very supportive for researchers. Some of these 
Journal of Educational Method and Technology Vol. 2 No. 3, Desember 2019

P-ISSN 2622-8459 E-ISSN 2622-8467

http://ejournal.unima.ac.id/index.php/jemtec

factors are: The attitude of the students who were very enthusiastic made the researchers very enthusiastic in carrying out and completing this research. Another factor that is also very supportive is the Japanese language instructor at the School of Nursing who is very helpful in conducting this research so that the research runs smoothly. Other supporting factors are the institution namely the "Bethesda" Nursing Academy in Tomohon City which is very cooperative so it is very helpful for researchers data collection process mainly in the form of written data through existing documents.

The implementation of this research has been systematically designed and endeavored to follow the procedures and rules of research to the maximum. In addition, it has also been carried out in accordance with the objectives of the study and through long stages in accordance with the mechanism. However, in this study there are still some limitations. The limitation in this research is that it is a weakness or weakness, that is, data collection for needs analysis is only done at one institution, the "Bethesda" Nursing Academy in Tomohon.

\section{Conclusion and Suggestion}

The results of the needs analysis and document analysis found that both learners, instructors and users need teaching materials that match the needs in the nursing department. The needs referred to include the material / content and its complement in the form of media even to its physical form.

Based on the results of the analysis presented in the above conclusions, it can be suggested the following things: First, the instructor or school can use textbooks that contain the correct material about topics that are closely related to the department in the field of tourism / hospitality in the learning process at school. Second, if the appropriate textbooks are not yet available, the instructor / teacher needs to be creative to make materials even though they are taken from various sources, and Third, a teaching project procurement project should be held through research and development involving experts both in Japanese and expert in the field of model development. Besides that, in order to develop a suitable Japanese teaching material model, and through a needs analysis.

\section{References}

Amirin, Tatang M. Pokok-pokok Teori Sistem. Jakarta: Rajawali, 1987.

Branch, Robert Maribe., Instructional Design: The ADDIE Approach. New York: Springer, 2009

Brown, Douglas H.. Prinsip Pembelajaran dan Pengajaran Bahasa (Edisi Kelima.) Pearson Education, Inc. 2007. Terjemahan Noor Cholis dan Yusi Avianto Pareanom

Brown, James Dean., The Elements of Language Curriculum; A Systematic Approach to Program Development. Boston; Heinle \& Heinle Publisher, 1995

Creswell John W., Research Design Pendekatan Kualitatif, Kuantitatif, dan Mixed. terjemahan Achmad Fawaid. Yogyakarta: Pustaka Pelajar, cetakan ke IV, 2014

Cunningsworth, A. Choosing your Coursebook..Oxford Heinemann, 1995

Dick W., L. Carey dan J.O. Carey. The Systematic Design of Instruction . Boston, Pearson-Edisi ke 6, 2005 
Journal of Educational Method and Technology Vol. 2 No. 3, Desember 2019

P-ISSN 2622-8459 E-ISSN 2622-8467

http://ejournal.unima.ac.id/index.php/jemtec

Emzir, Metodologi Penelitian Pendidikan Kuantitatif dan Kualitatif (Ed. Revisi), Jakarta: PT Raja Grafindo Persada, cetakan ke IV, 2014

Gagne, Robert M. dan Leslie J. Briggs, Principles of Instructional Design. New York: Holt, Rinehart and Winston, 1979.

Hutchinson, Tom dan Alan Water, English for specific Purposess; A learning Centered Approach, Cambridge: Cambridge University Press, 1987

Johnson, Elaine B. CTL. Contextual Teaching and Learning. Menjadikan Kegiatan belajar- mengajar Mengasyikkan dan Bermakna terjemahan Ibnu Setiawan.. Bandung: Kaifa Terbitan ed. Baru, cetakan ke III, 2011

Jolly, David dan Rod Bolitho "A framework for material writing" dalam Tomlinson (Ed) Materials Development in Language Teaching Cambridge: Cambridge University Press, 1998

Kemp, Jerrold E. Proses Perancangan Pengajaran. Terjemahan Asril Marjohan. Bandung: ITB, 1994.

Munir, Kurikulum Berbasis Teknologi Informasi dan Kumunikasi.Bandung: CV.Alfabeta, 2010

Muray, Print, Curriculum Development and Design. Sidney: Allen and Unwin, 1993.

Platt, Elizabeth. "Vocational/ VESL. Teacher Collaboration: Some Substative Issues". English for Specific Purposes An International Journal, New York: Pergamon Press, 1993, Vol. 12: 139-157.

Richards, Jack C. Curriculum Development in Language Teaching. Cambridge: Cambridge University Press, 2005

Rubdy, Rani. 'Selection of Materials', dalam B. Tomlinson (ed.) Developing Materials for Language Teaching. London: Continum, 2007

Richey, Rita C. dan Klein, James D. Design And Development Research. Methods, Strategies, and Issues. London: Lawrence Erlbaum Associates, 2007

Rusman, Model-model Pembelajaran: Mengembangkan Profesionalisme Guru..Ed. 2, Cetakan ke -5, Jakarta: Rajawali Pers, 2012

Shambaugh, Neal dan Susan G. Magliaro, instructional Design: A Systematic Approach for Reflective Practice. Boston: Pearson Education, Inc., 2006

Soekamto, Toeti, Perancangan dan Pengembangan Sistem Instruksional. Jakarta: Intermedia, 1993

Stoner, James A.F. dan R. Edward Freeman, Management. USA: Prentice-Hall, Inc. 1992

Sugiyono, Metode Penelitian Pendidikan.Pendekatan Kuantitatif, Kualitatif dan $R \& D$ Bandung: Alfabeta, 2010

Tomlinson, Brian (ed). Developing Materials for Language Teaching. London: Continum, 2007

------, Materials Development in Language Teaching. Cambidge, Cambridge University Press, 1998. 